\title{
The hyper-regulation of public space: the use and abuse of Public Spaces Protection Orders in England and Wales
}

\author{
Kevin J. Brown \\ Lecturer in Law, Queen's University Belfast \\ Contemporary state authorities in the United Kingdom and elsewhere have increasingly \\ sought to regulate the use of public space. This paper explores through a doctrinal and \\ socio-legal analysis how recently introduced Public Spaces Protection Orders (PSPOs) \\ are being used in England and Wales to enforce majoritarian sensibilities at the expense \\ of due process and civil liberties. PSPOs were introduced in October 2014. These orders \\ grant considerable discretion to local authorities to use the threat of criminal sanction to \\ regulate activities in public spaces that they regard as being detrimental to the quality of life \\ of residents. This paper provides the first comprehensive critique of how these orders are \\ used to target minority and vulnerable groups, while curtailing fundamental freedoms. \\ The paper includes suggestions for reforms to make the PSPO function in a manner that \\ is more compatible with a rights-based approach.
}

Dr Kevin J. Brown, School of Law, Queen's University Belfast, 27-30 University Square, Belfast BT7 1NN, UK. Email: k.brown@qub.ac.uk

\section{INTRODUCTION}

Over the past two decades, state authorities in the UK and elsewhere have increasingly sought to control the use of public space. These controls have been introduced to meet a range of policy objectives including the protection of public safety, ${ }^{1}$ the prevention of terrorism ${ }^{2}$ and gentrification. ${ }^{3}$ Various legal mechanisms and technologies have been used in pursuit of these objectives, including the privatization of once public space, ${ }^{4}$

* With thanks to Fiona Leverick and the anonymous reviewers for their comments. All errors remain those of the author.

1. A Barker 'Mediated conviviality and the urban social order: reframing the regulation of public space' (2016) Br J Crim (early online publication: ISSN 1464-3529); C Little 'The "Mosquito" and the transformation of British public space' (2015) 18(2) J Youth Stud 167.

2. J Coaffee 'Normalising exceptional public space security: the spatial fix of the Olympic carceral' in M De Backer et al. (eds) Order and Conflict in Public Space (Abingdon: Routledge, 2016) p 15; J Coaffee Terrorism, Risk and the Global City: Towards Urban Resilience (Abingdon, Routledge, 2009).

3. PL Doan and H Higgins 'The demise of queer space? Resurgent gentrification and the assimilation of LGBT neighborhoods' (2011) 31(1) J Planning Educ \& Res 6; E Anderson 'The white space' (2015) 1(1) Sociol Race \& Ethnicity 10.

4. K Landman 'Privatising public space in post-apartheid South African cities through neighbourhood enclosures' (2006) 66(1) Geo Journal 133; M Voyce 'Shopping malls in Australia: the end of public space and the rise of "consumerist citizenship"?' (2006) 42(3) J Sociol 269. 
exclusion from public space ${ }^{5}$ and the criminalisation of certain forms of behaviour within those spaces. ${ }^{6}$ The curtailment of the use of public space has the potential to impinge upon fundamental democratic rights, including freedom of assembly, freedom of expression, equality before the law and the protection of human dignity. ${ }^{7}$ As Moeckli acknowledges in his 2016 comparative analysis of the constitutional implications of limiting access to public space, surprisingly little legal academic attention has been paid to date to this important subject. ${ }^{8}$ This paper seeks to contribute to filling the gap in the literature through a doctrinal and socio-legal analysis of the use of Public Spaces Protection Orders (PSPOs). The PSPO is a new legislative measure which, since 2014, has provided extensive powers to local authorities to curtail the use of public space in England and Wales.

PSPOs were introduced to England and Wales in October 2014 by the then Conservative-Liberal Democrat Coalition Government. ${ }^{9}$ They are one legal tool among a package of measures designed to enhance local agencies' abilities to reduce antisocial and nuisance behaviour. ${ }^{10}$ PSPOs did not prove especially controversial when their introduction was debated in Parliament; indeed, the opposition Labour Party largely supported them. However, less than 2 years since their introduction, their use has led to protests and petitions alleging that PSPOs are being used by some local authorities to stifle fundamental freedoms and target vulnerable minorities. This paper provides the first comprehensive academic critique of this troubling new legal tool for controlling the use of public space.

PSPOs permit local authorities to place restrictions, backed up by the threat of criminal sanction, on the use of public space. A local authority may make a PSPO if satisfied on reasonable grounds that two conditions have been met. The first condition is that the activities they wish to target have had, or are likely to have, a detrimental effect on the quality of life of those in the locality. ${ }^{11}$ The second condition is that the effect or likely effect of the activities is, or is likely to be, of a persistent or continuing nature, is such as to make the activities unreasonable and that therefore restrictions on the behaviour are justified. ${ }^{12}$ A PSPO can prohibit specified activities being carried out in the restricted area or require specified things to be done by persons in the area, or indeed both. ${ }^{13}$ Breaching a condition of a PSPO - either a prohibition or a requirement - without reasonable excuse is a criminal offence, the maximum penalty for which is a

5. J Doherty et al. 'Homelessness and exclusion: regulating public space in European cities' (2008) 5(3) Surveillance \& Soc'y 290; A Von Hirsch and C Shearing 'Exclusion from public space' in A Vonirsch, D Garland and A Wakefield (eds) Ethical Perspectives in Situational Crime Prevention (Oxford: Hart Publishing, 2001) p 77.

6. DM Brown 'Young people, anti-social behaviour and public space: the role of community wardens in policing the "ASBO generation"' (2013) 50(3) Urban Stud 538; F Reyntjens 'The privatisation and criminalisation of public space in the geopolitics of the Great Lakes region' (2005) 43(4) J Mod Afr Stud 587.

7. D Moeckli Exclusion from Public Space: A Comparative Constitutional Analysis (Cambridge: Cambridge University Press, 2016).

8. Ibid, p 3 .

9. Anti-social Behaviour, Crime and Policing Act 2014, Ch 2.

10. For an overview of those measures, seeHome Office Anti-social Behaviour, Crime and Policing Act 2014: Reform of Anti-social Behaviour Powers. Statutory Guidance for Frontline Professionals (London: Home Office, 2014).

11. The 2014 Act, s 59(2).

12. Ibid, s 59(3).

13. Ibid, s 59(4). 
level three fine (currently $£ 1,000) .{ }^{14}$ The legislation also allows for fixed penalty notices to be used in place of a prosecution. ${ }^{15}$

This paper critically explores through a doctrinal and socio-legal analysis why PSPOs have proven so controversial. In doing so, this paper examines the legislation that governs PSPOs and the approach of local authorities to its implementation. It is argued that the use of PSPOs is undermining civil liberties associated with the use of public space and fundamental due process rights. A number of suggested reforms are set out to make PSPOs less troubling from a rights perspective.

\section{THE MISCHIEF BEHIND THE INTRODUCTION OF PSPOS}

Damian Green MP, the Minister for Policing and Criminal Justice at the time of the passage through Parliament of the Anti-social Behaviour, Crime and Policing Act 2014 (henceforth referred to as the 2014 Act), promoted PSPOs as follows:

We all agree that public spaces are there for the enjoyment of the whole community, and we all know that there is too often a minority who spoil it for the majority. Local authorities need effective powers to tackle that minority, and we want to give them the right powers to protect communities' enjoyment of their public spaces. ${ }^{16}$

Green's statement embodies authoritarian communitarian thinking, where the rights of citizens to make use of public space are forcibly balanced against citizens' responsibilities to ensure they use that space in manner that is consistent with others' ability to enjoy it. ${ }^{17}$ The approach is authoritarian as the state and its agents are enforcing majoritarian standards of conduct, rather than facilitating compromise and encouraging a dialogue between different categories of users of public space. ${ }^{18}$ This approach is further articulated in the statutory guidance that accompanies the PSPO legislation:

Public spaces protection orders (PSPOs) are intended to deal with a particular nuisance or problem in a particular area that is detrimental to the local community's qualify of life ... They are designed to ensure the law-abiding majority can use and enjoy public spaces, safe from anti-social behaviour. ${ }^{19}$

Labour Party ministers articulated similar arguments in the 1990s and 2000s to justify introducing measures designed to tackle antisocial behaviour and disorder. ${ }^{20}$ This included a more narrowly framed forerunner to the PSPO called the Designated Public Places Order, which allowed for the placement of restrictions on the

14. Ibid, s 67.

15. Ibid, s 68 .

16. Hansard HC Deb, col 265, 2 July 2013.

17. G Hughes 'Communitarianism and law and order' (1996) 16(49) Crit Soc Pol'y 17.

18. In a recent paper, Barker advocates an alternative mentality to authoritarian governance of public space that instead relies on a negotiated social order. She terms this 'mediated conviviality': Barker, above n 1. See also J Bannister and A Kearns 'The function and foundations of urban tolerance: encountering and engaging with difference in the city' (2013) 50(13) Urban Stud 2700.

19. Home Office, above n 10, p 47.

20. See eg The Labour Party A Quiet Life: Tough Action on Criminal Neighbours (London: Labour Party, 1995). 
consumption of alcohol in public places. ${ }^{21}$ It also included the controversial Antisocial Behaviour Order (ASBO). ${ }^{22}$ As with the PSPO, measures such as the ASBO (and its successors the Criminal Behaviour Order and the Anti-Social Behaviour Injunction) ${ }^{23}$ govern incivilities or nuisance, which are subjective categories of behaviour, the boundaries of which are based upon the shifting sands of public perception. ${ }^{24}$ In contrast to the PSPO, which governs behaviour in particular localities, the ASBO and its successors place restrictions on the behaviour of a particular individual. The ASBO was justifiably and roundly criticised for simultaneously facilitating the circumvention of traditional due process protections and encouraging the criminalisation of unpopular minorities and the activities in which they engage. ${ }^{25}$ The remainder of this paper will discuss how the PSPO in many ways is even more troubling than the ASBO.

\section{THE LEGAL TEST FOR A PSPO}

When considering the introduction of a PSPO, a local authority must apply the statutory test set out in s 59 of the 2014 Act. The two-stage test set out in the legislation does not require evidence of harm to any individuals, or even the potential for individuals to be harmed by the activities that are being targeted by a PSPO. This is a lower threshold than the now repealed ASBO and its successors, which require evidence that the behaviour in question is causing or is likely to cause harassment, alarm or distress to an individual. ${ }^{26}$

The first element of the legal test for a PSPO requires a local authority to be satisfied that 'activities they wish to target have had, or are likely to have, a detrimental effect on the quality of life of those in the locality'. ${ }^{27}$ Neither the statute nor the statutory guidance provides any further guidance on this aspect of the test. The term 'quality of life' is not defined in the legislation. According to the Collins English Dictionary, 'quality of life' is defined 'as the general well-being of a person or society, defined in terms of health and happiness, rather than wealth'. According to Baraccia et al., the concept began to be mentioned in research literature in the $1950 \mathrm{~s} .{ }^{28}$ In recent years there has been a growing interest in the concept of quality of life in many disciplines, including health, economics, philosophy, sociology and architecture. ${ }^{29}$ Organisations

21. Criminal Justice and Police Act 2001, ss 12-16 (repealed).

22. Crime and Disorder Act 1998, s 1 (repealed).

23. The 2014 Act, ss 1-33.

24. S McDonald "A suicidal woman, roaming pigs and a noisy trampolinist: refining the ASBO's definition of "anti-social behaviour"” (2006) 69(2) Mod L Rev 183.

25. A Ashworth 'Social control and "anti-social behaviour": the subversion of human rights' (2004) 120 Law Q Rev 263; AP Brown 'Anti-social behaviour, crime control and social control' (2004) 43(2) Howard J Crim Just 203; A Crawford 'Governing through anti-social behaviour: regulatory challenges to criminal justice' (2009) 49(6) Br J Crim 810.

26. Crime and Disorder Act 1998, s 1 (repealed); The 2014 Act, ss 1-33.

27. The 2014 Act, s 59(2).

28. B Barcaccia et al. 'Defining quality of life: a wild-goose chase?' (2013) 9(1) Europe's J Psychol; available at http://ejop.psychopen.eu/article/view/484/html (accessed 17 September 2016). 29. See eg $M$ Power, $M$ Bullinger and A Harper 'The World Health Organization WHOQOL-100: tests of the universality of quality of life in 15 different cultural groups worldwide' (1999) 18(5) Health Psychol 495; AL Ferriss 'The quality of life concept in sociology' (2004) 35(3) Am Sociol 37; M Nussbaum and A Sen (eds) The Quality of Life (Oxford: Oxford University Press, 1993). 
such as the EU, ${ }^{30}$ the World Health Organization ${ }^{31}$ and national governments ${ }^{32}$ have sought to measure levels of quality of life.

While interest has been growing in the concept, a clear and precise definition of 'quality of life' is lacking. For Baraccia et al., a difficulty in attempting to agree a definition of the concept and then to measure it is its subjectivity. ${ }^{33}$ What is important for one person's quality of life may not be important to another, or what may improve the quality of life of one person may undermine that of another. As an example, one person may find that young people congregating in the park impacts on their quality of life because they perceive it to be intimidating. Another passer-by may view the presence of a group as a positive sign of youthful vitality. The young people themselves may find the ability to congregate with others to be a vital component of their quality of life. If action is taken by a council to prohibit young people congregating through a PSPO, they may be improving the quality of life of the passer-by who finds the presence of the young people intimidating, but may ultimately undermine the quality of life of the young people and the passer-by who enjoyed the sight of them.

Other aspects of life that councils may choose to curtail through a PSPO pose the same dilemma. As will be discussed, a number of PSPOs target people sleeping on the street and people who beg: in such cases, the quality of life of those who do not wish to encounter such activities is outweighing the quality of life of those people who are in need of money to feed themselves or somewhere to sleep. The de facto criminalisation of begging and homelessness on grounds of nuisance and urban aesthetics runs counter to long-standing legal arguments that there is never sufficient justification to subject such activities to criminalisation. ${ }^{34}$

The second component of the test for a PSPO requires that a local authority is satisfied that the effect or likely effect of the activities:

- is, or is likely to be, of a persistent or continuing nature;

- is such as to make the activities unreasonable; and

- restrictions on the behaviour are justified. ${ }^{35}$

The first element of the second component is designed to dissuade local authorities from imposing restrictions on activities that occur as a one-off or only rarely. The terms 'persistent' and 'continuing' are, though, open to subjective interpretation. Furthermore, as the legislation allows for councils to take action where 'it is likely' that the activities will be persistent or continuing in nature, there is no need for a pattern of behaviour to actually have been established.

The second element of the second component of the test introduces a test of reasonableness. The local authority must satisfy themselves that the persistent or continuing activities that are, or are likely to, adversely impact on the quality of life of those in the locality are unreasonable. The third element of the second component of the test requires that local authorities satisfy themselves that the restrictions are justified. These two elements of the test should be important ones. It is here that the local

30. Eurostat Quality of Life: Facts and Views (Luxembourg: European Commission, 2015).

31. Power et al., above n 29.

32. Office for National Statistics Measuring National Well-Being: Life in the UK: 2016 (London: ONS, 2016)

33. Barcaccia et al., above n 28.

34. DJ Baker 'A critical evaluation of the historical and contemporary justifications for criminalizing begging' (2009) 73 J Crim L 212.

35. The 2014 Act, s 59(3). 
authority should satisfy themselves that they are appropriately balancing the needs of those who find the activities detrimental to their quality of life against the value of the activities to others, including those who engage in them.

In applying the legal test for a PSPO, councils will often find themselves balancing the quality of life of one group of individuals against that of another. The risk is that local authorities will often seek to protect the sensibilities of the 'law-abiding', 'respectable' majority, with whom they are more likely to share a world view of what types of activities are detrimental to that section of society's quality of life.

The balancing exercise should not be a simple majoritarian or utilitarian one, as to do so risks persecution of unpopular minorities and the activities in which they engage. Instead, it is argued here that where local authorities are considering regulating prima facie lawful activities through a PSPO, European Convention of Human Rights (ECHR) and judicial review jurisprudence should act as a guide. During the passage of the legislation through the House of Lords, an amendment was added to the 2014 Act requiring that all local authorities must have regard to the rights of freedom of expression and freedom of assembly as set out in Arts 10 and 11 of the ECHR. ${ }^{36}$ This provision has limited legal significance in that under s 6 of the Human Rights Act 1998, local authorities must already have regard to the convention rights in all of their actions, as they cannot purposefully act in contravention of these rights. However, the statutory provision in the 2014 Act at least serves as a reminder that the PSPO is a legal intervention that has the potential to lead to the contravention of certain convention rights associated with public space. In line with ECHR and judicial review jurisprudence, the local authority should be satisfied that the proposed restriction or prohibition is not arbitrary, unfair or based on irrational considerations, ${ }^{37}$ it does no more than is necessary to accomplish its legitimate aim $;{ }^{38}$ and that any interference with the rights of individuals is proportionate to the harm or potential harm caused. ${ }^{39}$ Given that PSPOs grant significant discretion to law enforcers, the risk of arbitrary enforcement of a provision should be considered when deciding whether or not to issue a PSPO and the framing of any prohibition or requirement. ${ }^{40}$

In response to concerns expressed by parliamentarians during the passage of the Bill, Lord Taylor of Holbeach, speaking on behalf of the government, sought to reassure peers as to how the test should be applied by local authorities:

Where orders are deemed to be unnecessary or disproportionate, there is still the ability for those affected to challenge it in court. The council will be mindful of this when judging whether the test has been met ... The benefit to the community in tackling detrimental activities must be balanced against the impact of any prohibitions or requirements. I believe that local councils are capable of making such assessments and coming to the right decisions, having consulted the local community. If they get it wrong, or are perceived to have got it wrong, an order can be challenged in the courts. ${ }^{4}$

36. Ibid, s 72(1).

37. Associated Provincial Picture Houses Ltd v Wednesbury Corporation [1948] 1 KB 223; Council of Civil Service Unions v Minister for the Civil Service [1983] UKHL 6.

38. The Sunday Times $v$ The United Kingdom (1979) 2 EHRR 245.

39. $R$ (on the application of Daly) $v$ Secretary of State for the Home Department [2001] 3 All ER 433.

40. Malone $v$ The United Kingdom (1984) 7 EHRR 14.

41. Hansard HL Deb, col 1221, 25 November 2013. 
Lord Holbeach expresses confidence that local authorities will read into the test terms such as 'necessity' and 'proportionately' and that where they fail to do so, the courts will step into remedy the situation. However, as will be discussed later in the paper, there is limited scope for challenging PSPOs in the courts, meaning that local authority decision makers may not have the risk of judicial intervention in mind when applying the test. The government should have made tests of 'necessity' and 'proportionately' explicit in the statute, to avoid any ambiguities. Precedent for such an approach existed, as a test of necessity was incorporated into the legislation governing the ASBO. ${ }^{42}$

The final part of the second component of the test for a PSPO requires justification. A justification requirement suggests that local authorities must have good reasons for acting and be able to provide those reasons. The risk is that local authorities will fall back on the other limbs of the test by justifying the introduction of a prohibition or restriction by simply stating that it is detrimental to quality of life and is persistent or of a continuing nature. Instead, in seeking to justify a condition they should establish how and to what extent quality of life is undermined. They should be satisfied that objective evidence supports this. They should also investigate the extent to which targeting the activity would be detrimental to the quality of life of those who engage in it. If a decision is made to target the activity, then assuming that in and of itself it is not unlawful, the local authority should satisfy itself that there is alternative provision for those who wish to engage in the activity. Unfortunately, as will be discussed later in the paper, the evidence thus far suggests that local authorities are not adopting such a rigorous approach.

Overall, the legal test for a PSPO undermines the minimalist approach to criminalisation and its associated principles as advocated by Ashworth and others. ${ }^{43}$ The legal test for a PSPO permits the criminalisation of behaviour in cases where traditional thresholds for criminalisation have not been established. There is no requirement that the regulated behaviour be directly or even remotely harmful, offensive or immoral. The test for the PSPO therefore fails to acknowledge the rights of those using public space in a non-normatively wrongful or harmful manner to be protected from punishment. $^{44}$

The widely framed test for a PSPO does not treat criminalisation as a last resort, as it encourages local authorities to seek recourse to the criminal law in response to behaviour that could be dealt with by alternative methods such as welfarist responses, informal social control or civil measures. ${ }^{45}$ The test for a PSPO also undermines the minimalist approach by allowing local authorities to use the criminal law in a manner that potentially undermines respect for human rights associated with the use of public space. ${ }^{46}$ Another component of the minimalist approach is the principle of not

42. Crime and Disorder Act 1998, s 1(1)(b).

43. A Ashworth Principles of Criminal Law (Oxford: Oxford University Press, 6th edn, 2009) ch 2 .

44. D Husak Overcriminalisation: The Limits of the Criminal Law (Oxford: Oxford University Press, 2008) pp 95-101.

45. An alternative perspective is to view the PSPO as promoting under-criminalisation in the sense that it is an administrative measure that facilitates the avoidance of traditional procedural protections associated with the criminal law. For a discussion of this perspective in relation to other preventive orders, see L Zedner and A Ashworth 'Preventative orders: a problem of undercriminalisation' in RA Duff et al. (eds) The Boundaries of Criminal Law (Oxford: Oxford University Press) p 59.

46. Ashworth, above n 43, pp 31-32. 
criminalising where this would be counterproductive; that is, where the risk of causing social harm in criminalising the behaviour is worse than in not doing so. ${ }^{47}$ As will be discussed later in this paper, the approach of some local authorities to PSPOs fails to consider the social harm caused by the criminalisation of certain activities in public space. If local authorities were to have in mind the minimalist approach and associated principles when considering a PSPO, the risk of the misuse of the order would be greatly diminished.

\section{A PUBLIC PLACE}

A PSPO must identify the public place to which it applies. ${ }^{48}$ The area covered by the order is referred to in the legislation as the 'restricted area' ${ }^{49}$ The legislation does not stipulate how the restricted area should be identified, but in practice PSPOs usually identify the area through a written description and/or an accompanying map. ${ }^{50}$ 'Public place' is given an expansive interpretation under the legislation, meaning 'any place to which the public or any section of the public has access, on payment or otherwise, as of right or by virtue of express or implied permission'. ${ }^{51}$ Very similar wording is found in legislation covering a range of offences including those governing road traffic offences, the carrying of weapons in public, and being drunk or disorderly in public. ${ }^{52}$

The definition of 'public place' covers what would be typically recognised as a public place, including council-owned or -administered roads, pathways, squares, greens, commons, parks, playgrounds and similar spaces. However, the definition of a "public place' can apply to a much wider range of spaces than these. The accompanying statutory guidance on PSPOs gives the example of a shopping centre as falling within the definition. ${ }^{53}$ Case law on other legislation using a similar definition of a "public place' has held that any spaces where the public or sections of the public have at least a limited right of access can fall within the definition. ${ }^{54}$ This includes spaces whether indoors or outdoors, whether publically or privately owned. Likely quasi-public targets for PSPOs include council-administered buildings such as libraries, public transport hubs, sports fields and stadiums, as well as shopping precincts.

The only restriction on the size of the area is the boundaries of the local authority. ${ }^{55} \mathrm{~A}$ number of local authorities when introducing a PSPO have covered large areas including entire town centres, which raises questions regarding the necessity and proportionality of such widely framed restrictions on the use of public space. ${ }^{56}$

47. Ibid, pp 33-34; Husak, above n 44, ch 3.

48. The 2014 Act, s 59(4).

49. Ibid, s 59(4).

50. See eg Salford City Council, PSPO 1 of 2015; available at https://www.salford.gov.uk/ media/388279/salford-quays-public-spaces-protection-order.pdf (accessed 17 September 2016). 51. The 2014 Act, s 74(1).

52. The Prevention of Crime Act 1953, s 1; Criminal Justice Act 1988, s 139; Criminal Justice Act 1967, s 91; Road Traffic Act 1930, s 7; Road Traffic Act 1988, s 5.

53. Home Office, above n 10, p 48.

54. Harriot $v$ DPP [2005] EWHC 965; $R$ v Leroy Roberts [2003] EWCA Crim 2753; DPP v Greenwood [1997] EWHC 129; Filmer v DPP [2006] EWHC 3450.

55. The 2014 Act, s 59.

56. See eg Chester City Public Spaces Protection Order 2016; available at http://www. cheshirewestandchester.gov.uk/your_council/public_notices/public_spaces_protection_order. aspx (accessed 17 September 2016). 


\section{WHO IS APPLYING THE TEST?}

In applying the test and granting the PSPO, local authorities do not need the approval of any court or central authority. Instead, central government has reassured opponents of the legislation that local democratic accountability is relied upon as a check on power. ${ }^{57}$ However, the legislation does not require the elected councillors to formally approve a PSPO through a vote in council or even a committee of council. The parliamentarian Lord Greaves had, during the passage of the legislation through the House of Lords, identified the risk that decisions regarding PSPOs would be taken with a lack of transparency by council officials. He advocated that the decision to grant a PSPO

should be made in public, because some of those decisions will be very controversial, and they should not simply be made by a delegated authority to an officer or to a cabinet member who makes the decision without having to justify it to people who wish to support it or protest against it. ${ }^{58}$

Lord Greaves proposed an amendment to the legislation that included the following:

A local authority must consider each decision on whether to make or amend a public spaces protection order in a committee of the authority meeting in public. ${ }^{59}$

The proposed amendment was not moved, following reassurances from ministers that councils would be instructed through government guidance to make the decisions in a democratic and transparent manner. Lord Greaves wryly remarked that the "Minister may tell me, "Of course that will happen - it will be in the guidance." I look forward to that. ${ }^{60}$ Lord Greaves was right to be sceptical, as no mention is to be found in the subsequent guidance on the appropriate forum for the council to debate the decision. Research by Appleton found that out of the 56 local authorities that had introduced a PSPO by February 2016, only nine were passed by a vote of the full council; 13 were passed by the cabinet or executive committee; four by a committee; two by two officers who shared authority to do so; while 28 were passed by a single council officer. ${ }^{61}$ Appleton found that where a PSPO was subject to a full vote at council, the draft order was more likely to be either rejected or amended. ${ }^{62}$ Appleton's findings are concerning, as they establish that unelected individuals are imposing localised criminal codes on entire communities with limited oversight and scrutiny. These individuals have considerable power to define boundaries of acceptable behaviour in public spaces and to exclude through criminalisation those who are deemed not to be behaving within the confines of acceptability.

Under an amendment to the Bill made in the House of Lords, the Home Secretary may designate power to issue PSPOs to a body or person other than a local authority. ${ }^{63}$ The only requirements or prohibitions that a designated person or body

57. Home Office, above $\mathrm{n} 10$.

58. Hansard HL Deb, col 1230, 25 November 2013.

59. Hansard Fourth Marshalled List Of Amendments To Be Moved In Committee: House of Lords. Amendment 39.

60. Hansard, above $\mathrm{n} 58$.

61. J Appleton PSPOs: A Busybodies' Charter (2016, The Manifesto Club); available at http:// manifestoclub.info/psposreport/ (accessed 17 September 2016).

62. Ibid.

63. The 2014 Act, s 71 . 
may include in a PSPO are those in respect of which it has the power to make a byelaw. ${ }^{64}$ PSPOs issued by local authorities will take precedence over those issued by designated persons or bodies. A designated body or person can, however, issue a notice to a local authority that has the effect that its byelaws take precedence over the local authority's PSPO. ${ }^{65}$ A PSPO from a designated body may cover the same space as one granted by a local authority, but cannot seek to regulate the same activities on that space. ${ }^{66}$ Thus far, only the City of London Corporation has been designated as such a body. ${ }^{67}$ This provision appears uncontroversial, as the designated person or body is restricted to making PSPOs to regulate activities that they already have the authority to regulate through byelaws; however, PSPOs have greater enforcement powers than most byelaws, meaning that this provision marks an increase in punitive power for such bodies.

\section{CONSULTATION AND PUBLICATION OF PSPOS}

In an attempt to ensure that PSPOs reflect the needs of local communities, prior to issuing a PSPO a local authority must carry out 'the necessary consultation'. ${ }^{6}$ The legislation requires that the local authority consult with the relevant chief constable and local policing body (in most localities, the Police and Crime Commissioner), the owner or occupier of the land (assuming it is not the local authority itself) and whatever 'community representative the local authority thinks it appropriate to consult'. ${ }^{69}$ This latter requirement grants local authorities extensive discretion to consult with who they believe represents the 'community'. The risk is that those who are consulted may not be truly representative of the users of the relevant public space. Those groups that may be disproportionately affected by the terms of a PSPO, such as the homeless, young people, some ethnic minority groups and the traveller community, are particularly hard to reach when it comes to consultations. ${ }^{70}$ Local authorities should avoid the temptation to consult only with those who they believe will be protected by the measures, rather than those who will be restricted by them.

A local authority must also carry out the 'necessary publicity', which includes publishing the text of the proposed order on their website and erecting such notice or notices as it considers sufficient to draw the attention of any member of the public using the area that an order has been made. ${ }^{71}$ Again, the statutory provisions grant local authorities significant discretion. Promotion on a local government website may garner little attention, particularly if not associated with social media engagement. Having sufficient physical notices is important, although it is for the local authority to decide how many notices are required to be placed in the area to be covered by the PSPO.

64. Ibid, s 71(3).

65. Ibid, s 71(6).

66. Ibid, ss 71(4), 71(5).

67. Anti-social Behaviour (Designation of the City of London Corporation) Order 2015/858.

68. The 2014 Act, s 72.

69. Ibid, s 72(4).

70. T Jones and T Newburn Widening Access: Improving Police Relations with Hard To Reach Groups (London: Home Office, 2001).

71. Anti-social Behaviour, Crime and Policing Act 2014 (Publication of Public Spaces Protection Orders) Regulations 2014/2591. 


\section{THE CONDITIONS OF A PSPO}

A PSPO can prohibit specified activities being carried out in the restricted area or require specified things to be done by persons in the area, or indeed both. ${ }^{72}$ According to the statute, the only prohibitions or requirements that may be imposed are ones that are reasonable to prevent or reduce the risk of the detrimental effect on quality of life from continuing, occurring or reoccurring. ${ }^{73}$ An order can contain one or multiple prohibitions and requirements. Research by Appleton has found that the most common prohibitions are on the consumption of alcohol, while also popular are prohibitions on the consumption of legal highs. ${ }^{74}$

A prohibition or requirement may be framed so as to apply to all persons, or only to persons in specified categories or to all persons except those in specified categories. ${ }^{75}$ Some local authorities have explicitly framed the conditions of their PSPO to target young people. Bassetlaw Local Authority has a PSPO which states that:

persons 16 years or under, who are not under the effective control of a parent or a responsible person aged 18 or over, are prohibited from gathering in a the designated area in groups of 3 or more. This prohibition will only apply if any of the group is causing annoyance, harassment, alarm or distress ...

Such a provision directly discriminates against young people by singling them out as a target population for additional criminalisation. In framing the prohibition as widely as Bassetlaw Local Authority has done, it grants significant discretion to those enforcing the legislation to determine whether they wish to criminalise young people for being 'annoying', which is an extremely low threshold. Research on dispersal orders, a previous legal remedy targeted against young people congregating, has shown that such prohibitions 'antagonise and alienate young people ... who frequently feel unfairly stigmatised for being in public places ${ }^{, 77}$ and "generate short-term displacement effects, shifting problems to other places'. ${ }^{78}$

The most far-reaching type of prohibition found within PSPOs are those that criminalise people for congregating in groups. Hillingdon Local Authority in London has granted a number of PSPOs that cover local town centres, with a prohibition on 'gathering in groups of two or more persons unless going to or from a parked vehicle or waiting for a scheduled bus at a designated bus stop'. ${ }^{79}$ There is no requirement that the persons within the group of two or more persons be engaging in any antisocial or nuisance behaviour. In these designated areas of Hillingdon, unless you are at a bus stop or on the way to or from a parked vehicle, everything is forbidden if you are in the company of another person unless the authorities use their discretion to permit it. This runs completely contrary to the

72. The 2014 Act, s 59(4).

73. Ibid, s 59(5).

74. Appleton, above $\mathrm{n} 61$.

75. The 2014 Act, s 59(6).

76. Gateford Public Spaces Protection Order 2015.

77. A Crawford 'Dispersal powers and the symbolic role of anti-social behaviour legislation' (2008) 71(5) Mod L Rev 753-776.

78. Ibid, at 766 .

79. See Hayes Town Centre PSPO, Eastcote PSPO, Yeading PSPO and Pinkwell PSPO. Copies are available at https://www.hillingdon.gov.uk/pspo (accessed 17 September 2016). 
principle of minimal criminalisation and is an inversion of the constitutional principle of English law that 'everything which is not forbidden is allowed'. Clearly, this prohibition is designed to be enforced selectively. Therefore, it grants significant discretion to police officers and other enforcement officers to selectively enforce the law. This arbitrary enforcement creates a risk that perceived undesirable groups, such as the homeless, beggars, children and young people, and racial and ethnic minorities, will be targeted. It may not be the council's intention to facilitate the risk of such discrimination, but research studies have shown time and again that granting significant discretion in the application of the criminal law results in disproportionate application on particular sections of society. ${ }^{80}$

Young people are disproportionately more likely to fall foul of provisions such as those passed by Hillingdon Local Authority. This is because they are more likely to gather in groups in public and quasi-public spaces than adults, as they are often more limited in terms of options as to where they may associate with one another and enjoy leisure time. ${ }^{81}$ Groups of young people are also more likely to be perceived as intimidating than other age groups, meaning that the police are more likely to come under pressure to enforce the provisions against young people. ${ }^{82}$ Other prohibitions that have been seen in some PSPOs, which will also disproportionately impact on young people, are prohibitions on popular leisure activities, including skateboarding and rollerblading. ${ }^{83}$ Local authorities that choose to criminalise the activities of young people in this manner are failing to adequately consider the social harm caused to young people.

A number of PSPOs have sought to prohibit swearing in designated public places. This includes a PSPO introduced by Salford Council that prohibits 'using foul and abusive language' in the Salford Quays area. ${ }^{84}$ No further elaboration on what will count as either 'foul' or abusive' is provided in the PSPO document. It is not clear what legal test is applied to establish if there has been a breach of this prohibition. Presumably, the council is leaving it to the police or other officials to use their discretion when enforcing it. The risks of that discretion being misused are real, particularly when fixed penalties are in use. This is because an accused person is likely to accept a fixed penalty to discharge liability, meaning that such a case is unlikely to reach the stage of being reviewed by the Crown Prosecution Service or a criminal court. Criminalising speech in such an arbitrary manner without any requirement to establish any harm or potential harm disproportionately undermines freedom of expression.

80. See eg B Bowling and C Phillips 'Disproportionate and discriminatory: reviewing the evidence on police stop and search' (2007) 70(6) Mod L Rev 936; J de Maillard et al. 'Different styles of policing: discretionary power in street controls by the public police in France and Germany' (2016) Policing \& Soc'y; T Burch 'Skin color and the criminal justice system: beyond black-white disparities in sentencing' (2015) 12(3) J Empirical Legal Stud 395.

81. C Johnstone 'After the Asbo: extending control over young people's use of public space in England and Wales' (2016) 36(4) Crit Soc Pol'y 716.

82. A Crawford 'Criminalizing sociability through anti-social behaviour legislation: dispersal powers, young people and the police' (2009) 9(1) Youth Just 5; Johnstone, above n 81.

83. S Sandhu 'Street skaters may find their latest moves land them in court - but they are fighting back' The Independent 1 August 2015; available at http://www.independent.co.uk/ news/uk/home-news/street-skaters-may-find-their-latest-moves-land-them-in-court-but-theyare-fighting-back-10432783.html (accessed 17 September 2016).

84. Salford City Council (Salford Quays) Public Spaces Protection Order 1 of 2015. 
Some PSPOs have sought to restrict the right of people to voice opinions by prohibiting public orators or speakers who make use of amplification equipment. The UK has a long tradition of open-air public speaking on matters political and religious. ${ }^{85}$ Authorities have tended not to intervene to curtail open-air public speaking unless it constitutes a public order offence. In 2015, Birmingham City Council abandoned plans for a PSPO that would have prohibited the use of amplification in any circumstances by buskers, street entertainers and street speakers in part of the city centre, which included an area that had historically been used by street speakers. ${ }^{86}$ The Birmingham City Council proposal would arguably have disproportionately restricted the right to freedom of expression as well as the right of freedom of religion. Birmingham City Council was ultimately dissuaded from pursuing its proposals following a campaign against them; otherwise, the proposals would probably have come into force. ${ }^{87}$

Particularly controversial have been conditions in PSPOs that have targeted the homeless. A number of local authorities have introduced or sought to introduce provisions that prohibit rough sleeping and/or begging. A particularly widely framed provision on sleeping covering almost the entire area of Folkestone was passed by Shepway District Council in 2015. ${ }^{88}$ It reads as follows:

All persons are prohibited from sleeping in any public place which is or includes:

- Open to the air;

- Within a vehicle;

- Within a carpark;

- A non-fixed structure including caravans and tents

Without the prior permissions of the owner or occupier of the land other than a place designated for the purpose of sleeping including designated camp sites. ${ }^{89}$

This provision covers people who may be sleeping rough in a doorway or on a park bench. It also appears to be targeted at members of the traveller and gypsy communities who are sleeping in their caravans on sites that are not designated for that purpose. Such wide-ranging provisions on where people sleep are reminiscent of the anti-vagrancy attitudes of the nineteenth century. ${ }^{90}$ This agenda of banishing from the streets the 'unclean' or 'desirables' in the name of gentrification and clampdowns on incivilities is evocative of measures adopted in recent years in other jurisdictions, including the USA. ${ }^{91}$

85. JM Roberts 'The enigma of free speech: Speakers' Corner, the geography of governance and a crisis of rationality' (2000) 9(2) Social \& Legal Stud 271.

86. Birmingham City Council 'Public Spaces Protection Order consultation: noise from buskers, street entertainers and street speakers in the city centre' (Birmingham: Birmingham City Council, 2015); available at https://www.birminghambeheard.org.uk/place/the-introduction-ofpublic-spaces-protection-order/supporting_documents/PSPO\%20Appendices\%205and6.pdf (accessed 17 September 2016).

87. N Elkes 'Birmingham busker ban proposals are scrapped' Birmingham Post 17 September 2015; available at http://www.birminghampost.co.uk/news/regional-affairs/birmingham-buskerban-proposals-scrapped-10072778 (accessed 17 September 2016).

88. Public Spaces Protection Order (Shepway District Council) 2015 No 1.

89. Ibid.

90. Baker, n 34 .

91. K Beckett and S Herbert Banished: The New Social Control in Urban America (New York: Oxford University Press, 2010). 
In 2016, Newcastle City Council consulted on introducing a PSPO that is to prohibit begging on the street. ${ }^{92}$ The reasons given by the council for suggesting such a prohibition in its consultation were as follows:

Beggars often need long term help and support rather than short term donations; [begging] can be intimidating to the public; [begging] can be detrimental to businesses by putting shoppers off entering shops where beggars congregate. ${ }^{93}$

Arguments that individuals should be criminalised for their own protection are evidence of a neoliberal philosophy in action, where the criminal justice system and its associated sanctions are used in place of social welfare, a phenomenon referred to by Rodger as the criminalisation of social policy. ${ }^{94}$ The suggested prohibition from Newcastle City Council did not seek to limit itself to aggressive or intimidating begging; therefore, it is not clear what evidence the council was using to support its assertion that begging is intimidating to the public per se. Nor was it clear on what evidence the council was basing its assertion that shoppers are being put off entering shops by congregating beggars. The results of the consultation were mixed; out of 726 responses, $44.3 \%$ of consultees found begging to be problematic (although not necessarily intimidating) and $25.9 \%$ did not, with $29.9 \%$ not expressing views either way. ${ }^{95}$ The mixed response did not initially dissuade the council, which announced it was pressing ahead with its plans to introduce a PSPO containing a prohibition on begging. ${ }^{96}$ It was only after subsequent public protests that the council relented and agreed to focus the PSPO on so-called 'aggressive begging'. ${ }^{97}$ Newcastle's failings demonstrate the importance of local authorities conducting genuine consultations where they actively engage with hard-to-reach groups that may be affected by the PSPO.

\section{RENEWING AND VARIATION OF PSPOS}

PSPOs have an initial maximum duration of 3 years, whereupon they may be renewed for a further maximum 3-year period. ${ }^{98}$ There are no limits on the number of extensions that can be made. ${ }^{99}$ The test for renewing the order is that the local authority is satisfied on reasonable grounds that doing so is necessary to prevent an occurrence or

92. Newcastle City Council 'Newcastle upon Tyne: Public Spaces Protection Order: consultation document' (Newcastle upon Tyne: Newcastle City Council, 2016); available at https://letstalknewcastle.co.uk/files/2016_PSPO_consultation.pdf (accessed 17 September 2016).

93. Ibid.

94. JJ Rodger Criminalising Social Policy: Anti-social Behaviour and Welfare in a DeCivilised Society (Cullompton: Willan, 2008).

95. Newcastle City Council 'Cracking down on anti-social behaviour'; available at https:// www.newcastle.gov.uk/news-story/cracking-down-anti-social-behaviour (accessed 17 September 2016).

96. Ibid.

97. A Praharaj 'City protest over Newcastle City Council's proposed 'begging ban" 7 December 2016; available at http://www.chroniclelive.co.uk/news/north-east-news/cityprotest-over-newcastle-city-12284045 (accessed 25 May 2017).

98. The 2014 Act, s 60.

99. Ibid, s 60(4). 
reoccurrence of the activities identified in the order, or an increase in the frequency or seriousness of those activities. ${ }^{100}$ The explanatory notes accompanying the legislation refer to this test as a review process, which - given the low threshold of the renewal - is somewhat of a misnomer. The explanatory notes state the following:

The review requirements will be different depending on the prohibitions or requirements being applied - for instance, an order requiring dogs are kept on their leash in a children's play area is unlikely to necessitate the same level of review as an order prohibiting any access to a public place to deal with a short-term issue such as localised crime. ${ }^{101}$

Whether one refers to this as a review process or not (the explanatory guidance does although the statute does not), the test to be applied is a lower threshold test than that which is required to satisfy the need for a PSPO in the first place. Given the extensive discretion that PSPOs can provide local authorities and law enforcers to regulate prima facie legal activities and the absence of external scrutiny, in the interests of justice a local authority should be required to reapply the original legal test to satisfy itself that the PSPO and all of its conditions are still required. Furthermore, a proper review process should entail an examination of the impact of the PSPO both in terms of its effectiveness at reducing any undesirable activities, and also its impact on those whose activities have been curtailed.

The local authority must conduct a consultation prior to renewing the order, ${ }^{102}$ must publicise the changes, ${ }^{103}$ and must inform the chief of police, the local policing body, whatever community the local authority thinks appropriate and the owner or occupier of any land within the restricted area (assuming that the local authority is not the owner). ${ }^{104}$ After 3 years of an order being in place, police and majoritarian public expectations are likely to favour renewal for fear of a return to an unregulated public space.

As well as renewing an order, a local authority may vary or discharge an order at any time. ${ }^{105}$ Variation can include increasing or reducing the size of the restricted area, altering or removing a prohibition or requirement, or adding a new one. ${ }^{106}$ If the variation involves amending the restricted area to cover land not previously covered, or the addition of a new prohibition or requirement, or the extension of an existing prohibition or requirement the local authority, must reapply the original legal test for the PSPO. ${ }^{107} \mathrm{~A}$ fresh consultation must be conducted prior to the order being varied or discharged. ${ }^{108}$ In addition, any variation or discharge must be published in accordance with the regulations. ${ }^{109}$

100. Ibid, s 60(2).

101. Anti-social Behaviour, Crime and Policing Bill Explanatory Notes, para 146.

102. The 2014 Act, s 72 .

103. Ibid, s 60(3).

104. Ibid, s 72 .

105. Ibid, s 61.

106. Ibid.

107. Ibid, s 72 .

108. Ibid.

109. Ibid, ss 61(5), 61(6). 


\section{CONTRASTING PSPOS WITH BYELAWS}

PSPOs have much in common with byelaws, which local authorities have long been able to introduce to regulate various activities. Any byelaws that overlap with a PSPO are superseded for the duration of the order. ${ }^{110}$ There are several pieces of specific legislation that grant local authorities the power to make byelaws; in addition, under s 235 of the Local Government Act 1972, local authorities have a general power to make byelaws for 'the good rule and government of the whole or any part of the district' and 'the prevention and suppression of nuisances therein'.

An important limitation applying to byelaws, but not PSPOs, is that the latter are ultra vires 'if provision for that purpose as respects that area is made by, or is or may be made under, any other enactment'. ${ }^{11}$ Therefore, byelaws should not seek to cover activities that are already the subject of the criminal or civil law. In issuing PSPOs, local authorities are under no such restriction, providing them with the scope to include a significantly wider range of activities within the order than might be covered by a byelaw.

Unlike with PSPOs, a local authority intending to introduce new or amended byelaws must submit a draft of it to the relevant Secretary of State for approval. ${ }^{112}$ Most byelaws must be submitted to the Secretary of State for Communities and Local Government. An assessment of the regulatory burden that is imposed by the new byelaw must accompany the submission. ${ }^{113}$ The statement of assessment must cover the impact of the proposed byelaw on persons potentially affected by it; whether the byelaw results in an increase in the regulatory burden; and if it does, reasons why such an increase is considered to be proportionate and necessary. ${ }^{114}$ In establishing whether the regulatory burden imposed would be proportionate, the local authority is required to identify

- the objective which the proposed byelaw is seeking to secure;

- whether the objective intended to be secured by the proposed byelaw could be satisfactorily secured by alternative means;

- the impact of the proposed byelaw on all persons identified by the authority as being potentially affected by it;

- whether the result of the proposed byelaw would increase or lessen the regulatory burden on persons potentially affected by the proposed byelaw, insofar as possible expressing that increase or reduction in monetised form;

- how these alternative means and the proposed byelaw compare with carrying out no further action. ${ }^{115}$

The government deliberately avoided introducing similar oversight for PSPOs. The explanatory notes accompanying the legislation governing PSPOs states that to 'reduce bureaucracy' there is intended to be less central government oversight [of PSPOs] than with byelaws, and no central government reporting requirements. ${ }^{116}$

110. Ibid, s 70 .

111. Local Government Act 1972, s 235(3).

112. The following applies in England only: The Byelaws (Alternative Procedure) (England) Regulations 2016.

113. Ibid.

114. Ibid, Reg 5.

115. Ibid, Reg 5(2)(b).

116. Anti-social Behaviour, Crime and Policing Bill Explanatory Notes, para 155(b). 
Given that the most recent regulations governing the introduction of byelaws were introduced in 2016, it is peculiar that the level of 'bureaucracy', as the government labels it, is greater for byelaws than for PSPOs (the legislation for which dates back to 2014). Byelaws regulate the behaviour of businesses as well as that of individuals, whereas PSPOs focus on the regulation of the behaviour of individuals. When laws operate to govern the behaviour of businesses, the neoliberal philosophy of the current government views this as 'regulation', which should be scrutinised and minimised to reduce the 'regulatory burden' on those businesses. ${ }^{117}$ When laws operate to govern the behaviour of unpopular minorities such as young people, the homeless or the travelling community, concerns for 'regulatory burden' are abandoned and instead the emphasis is on reducing the 'bureaucratic burden' on public agencies to make it easier to introduce laws and enforce them. The burdens are inverted versions of one another: when one talks of a 'regulatory burden', it is about reducing the burden on those whom the law seeks to govern, whereas a 'bureaucratic burden' is about reducing the burden on the law makers and enforcers. The perverse aspect of such a bifurcation of approach is that businesses, which are more likely than individuals to have the means to challenge any laws they see as unjust, are more likely to be shielded by the government from the law. There is nothing to prevent local authorities conducting a regulatory burden test for PSPOs of their own volition, and it is arguably good practice for them to do so, to help reduce the risk of unnecessary restrictions being placed on otherwise lawful activities.

The consultation process for byelaws is more stringent than that for PSPOs. Under The Byelaws (Alternative Procedure) (England) Regulations 2016, a local authority must publish notice of the proposal for a byelaw on its website and in one or more local newspapers. ${ }^{118}$ The notice of the proposal must identify the land to which the byelaw will apply, give a summary of its intended effect, and specify the location of the local authority building where the notice may be inspected free of charge and at all reasonable hours, and the address from which a copy of the documents may be obtained on request. ${ }^{119}$ At least 28 days must be given from the date of publication of the notice during which the notice may be inspected and written representations on the proposed byelaw may be made. ${ }^{120}$ The explanatory notes accompanying the legislation governing PSPOs states that

There will be lighter touch consultation requirements to save costs (for example, there is no duty to advertise in local newspapers). This is following feedback in the consultation from local authorities that the current processes for consultation outlined in secondary legislation are costly and time-consuming. ${ }^{121}$

Here again, the government demonstrates a greater willingness to facilitate law makers when it comes to laws that affect individuals' personal behaviour rather than those that govern business. As with the regulatory burden test, there is nothing to prevent local authorities, if they so choose, from applying the same standard of consultation to a PSPO as they would with a byelaw, and doing so may make for fairer orders.

117. Conservative Party The Conservative Party Manifesto 2015 (London: Conservative Party, 2015).

118. The Byelaws (Alternative Procedure) (England) Regulations 2016, Reg 8(2).

119. Ibid, Reg 8.

120. Ibid, Reg 8(3).

121. Anti-social Behaviour, Crime and Policing Bill Explanatory Notes, para 155(c). 
PSPOs are easier to enforce than most byelaws, as a fixed penalty may be issued for breach of the former. Most byelaws require an authority wishing to enforce the byelaw to prosecute the alleged breach in court. ${ }^{122}$ This makes PSPOs quicker and cheaper to enforce. As will be discussed in the next section, the use of fixed penalties for PSPOs may make enforcement easier, but it also reduces the level of oversight and scrutiny of the orders and their enforcement.

\section{BREACH OF A PSPO}

Breaching a standard condition of a PSPO - either a prohibition or a requirement without reasonable excuse is a criminal offence, the maximum penalty for which is a level three fine (currently £1,000). ${ }^{123}$ The legislation also allows for fixed-penalty notices to be used in place of a prosecution. ${ }^{124} \mathrm{~A}$ fixed penalty can be issued by a police officer or other authorised person (which could include, among others, community support officers or authorised council officials) where they have reason to believe that an offence of breaching the PSPO has been committed. ${ }^{125}$ A 'reasonable belief' of an officer is a lower evidential standard than the criminal standard of 'beyond reasonable doubt'. ${ }^{126}$ If the person to whom the fixed-penalty notice is issued pays the penalty to the local authority, they discharge any liability for conviction for the offence. ${ }^{127}$ The advantages of fixed penalties are that they allow individuals to evade a potentially stigmatising criminal conviction while saving the considerable resources that prosecution in court entails. A disadvantage of fixed penalties is that they encourage individuals not to challenge allegations of criminal wrongdoing in court, which results in minimal judicial oversight, thereby reducing the likelihood that PSPOs and their potentially arbitrary enforcement will be effectively scrutinised. ${ }^{128}$

For PSPO prohibitions on alcohol consumption, the procedure in relation to breach functions somewhat differently. The legislation provides that where a police officer (or otherwise authorised person) reasonably believes that someone is, or was, consuming, or intends to consume, alcohol in breach of the prohibition, the officer may instruct the individual to cease consumption. ${ }^{129}$ Furthermore, the officer may instruct the individual to surrender to them the alcohol and/or the container that is suspected of containing the alcohol. ${ }^{130}$ The officer must inform the individual that failure to abide by the instructions constitutes a criminal offence, the maximum penalty for which is a level

122. Local Government Act 1972, s 237.

123. The 2014 Act, s 67.

124. Ibid, s 68 .

125. Ibid.

126. Jirehouse Capital v Beller [2008] EWCA Civ 908; Windsor v Crown Prosecution Service [2011] EWCA Crim 143.

127. The 2014 Act, s 68(2).

128. A Sanders, R Young and M Burton Criminal Justice (Oxford: Oxford University Press, 2010) pp 408-409; R Young Ethnic profiling and summary justice: An ominous silence? In K Sveinsson (ed), Ethnic Profiling: The Use of 'Race' in UK Law Enforcement (London: Runnymede Trust, 2010) pp 43-49; K Warner 'Equality before the law and equal impact of sanctions: doing justice to differences in wealth and employment status' in L Zedner and JV Roberts (eds), Principles and Values in Criminal Law and Criminal Justice: Essays in Honour of Andrew Ashworth (Oxford: Oxford University Press) pp 225-243.

129. The 2014 Act, ss 63(1), (2)(a).

130. Ibid, s 63(2)(b). 
two fine (currently £500). ${ }^{131}$ As with standard PSPO conditions, where there has been an admitted breach, a fixed penalty may be used in place of a prosecution. ${ }^{132}$ The approach in relation to alcohol consumption follows that of a previous legislative measure governing public space, which was abolished when the PSPO was introduced. ${ }^{133}$ By offering individuals the opportunity to conform to the conditions of the PSPO and avoid criminalisation or a fixed penalty, a more responsive approach to the regulation of behaviour is adopted. ${ }^{134}$ It is responsive in the sense that individuals are provided with the opportunity to weigh up the costs and benefits of compliance rather than facing immediate criminalisation (or a fixed penalty), as is the case with standard PSPO conditions. ${ }^{135}$

\section{CHALLENGING PSPOS IN THE COURTS}

The legislation governing PSPOs seeks to limit the opportunities to challenge an order in the courts. Under s 66 of the statute, legal challenges can be taken either (a) by 'an interested person' to the High Court within 6 weeks of the order being granted or (b) in the course of criminal proceedings by the person charged with breaching the order. ${ }^{136}$ There is no time limit for the latter route of challenge.

Under the first route of challenge, to be classified as 'an interested person', an individual must either live in the area, or regularly work in or visit the area covered by the PSPO. ${ }^{137}$ This provision deliberately excludes campaigning organisations such as Liberty or the Ramblers' Association. Although these groups are not able to instigate proceedings under this heading, there is nothing to prevent them from making an application for judicial review (discussed later in this section) or assisting financially or in kind individuals who meet the criteria to bring a legal challenge under s 66. Such support may be important, as a challenge to a PSPO brought under s 66 is governed by civil legal aid provisions, which means that applicants may struggle to attract government funding for proceedings. ${ }^{138}$

While a challenge is ongoing, the High Court may suspend the operation of the entire order or particular prohibitions or requirements contained within the order. ${ }^{139}$

The PSPO can be challenged in the High Court by an interested person under two grounds. The first is that the local authority did not have the power to make the order or variation or to include particular prohibitions or requirements (the ultra vires argument). ${ }^{140}$ Likely examples of where a local authority would be exceeding its authority would include where it sought to include a locality that was not a public space or was not within its local government area. It would also be exceeding its authority

131. Ibid, s 63(3).

132. Ibid, s 68.

133. The Criminal Justice and Police Act 2001, ss 12-16 (repealed).

134. Thank you to one of the anonymous reviewers for identifying this point.

135. J Braithwaite Restorative Justice and Responsive Regulation (Oxford: Oxford University Press, 2002); Crawford, above n 25.

136. The 2014 Act, s 66(1).

137. Ibid.

138. Legal Aid, Sentencing and Punishment of Offenders Act 2012 Pt I; House of Commons Justice Committee Impact of Changes to Civil Legal Aid under Part 1 of the Legal Aid, Sentencing and Punishment of Offenders Act 2012 HC311, 2015.

139. The 2014 Act, s 66(4).

140. Ibid, s 66(2)(a). 
where the legal test for the granting of a PSPO or the inclusion of a specific prohibition or requirement has not been satisfied. If the High Court is satisfied that a local authority did not have the power, the Court may quash the order or variation of the order or particular prohibitions or requirements. ${ }^{141}$

The second ground under the first route of challenge is that the local authority did not comply with the requirements under the 2014 Act regarding the creation or variation of a PSPO. ${ }^{142}$ The High Court may only quash a PSPO or provisions contained within it under this ground if it is satisfied that the interests of the applicant have been substantially prejudiced by a failure to comply with a requirement under the legislation. ${ }^{143}$ The second ground sets a high threshold, as it requires the applicant to do more than establish that a requirement of the legislation was not complied with: they must also establish that they personally have been substantially prejudiced by the failure to comply. For example, an interested person may challenge a PSPO on the basis that consultation or publication requirements were not complied with; however, merely establishing this will not be sufficient if they do not also establish substantial prejudice.

Challenges to the High Court must be taken with 6 weeks of the order being granted. This tight time frame is considerably shorter than the 3-month time limit for individuals to make an application for judicial review proceedings. One can envisage scenarios where an applicant only becomes aware of the PSPO or only realises that there is a problem with a PSPO after the 6-week period. For example, if a person moves into or takes up employment in an area, or becomes a regular visitor to the area, more than 6 weeks after the order has been granted, then they will not be able to challenge the order unless they are prosecuted for breach.

The limited opportunity to utilise the High Court challenge route, including the limitations placed on access to civil legal aid, may encourage individuals unhappy with a PSPO to challenge the order by instead flouting the order to test the resolve of the local authority and enforcement agencies. Under the legislation, a person facing criminal proceedings for breach of a PSPO will escape liability if they can establish that the local authority did not have the power to include the particular prohibition or requirement that the person is alleged to have breached. ${ }^{144}$ This amounts to a challenge of sorts to the order, although only in relation to the relevant condition. If the person is prosecuted, they then gain access to a court, which provides an opportunity to review the relevant condition of the PSPO. Such a person must be willing to face the risk of an unsuccessful challenge, a finding of guilt and a subsequent criminal record. A criminal record, even for what might be perceived as a relatively minor crime, can have a stigmatising effect, with a potentially adverse impact on employment and educational opportunities, international travel, access to social housing, mortgages and insurance policies. ${ }^{145}$

The legislation as originally framed deliberately sought to exclude judicial review proceedings as a forum for challenging PSPOs, limiting challenges instead to the

141. Ibid, s 66(5).

142. Ibid, s 66(2)(b).

143. Ibid, s 66(5).

144. Ibid, s 67(3).

145. J Abrahams 'What can't you do with a criminal record?' Prospect Magazine 22 May 2013; available at http://www.prospectmagazine.co.uk/features/criminal-record-chris-huhne-vickypryce-adam-johnson (accessed 17 September 2016). 
routes discussed already in this section of the paper. However, following objections raised during the passage of the Bill in the House of Lords, the government accepted an amendment that has the effect of excluding 'interested persons' from taking judicial review proceedings, but 'ensur[ing] that judicial review remains open to persons other than interested persons, such as national bodies'. ${ }^{146}$ This is an important concession, which allows organisations representing particular interests and sections of society to take action without the need to wait for an individual from the locality to come forward. A range of organisations expressed concern about the potential use of PSPOs during the evidence stage of the legislative proceedings, including the Countryside Alliance, the Open Spaces Society, the Kennel Club, Liberty, Living Streets, the British Horse Society and the Rambler's Association. ${ }^{147}$ Many of these organisations have an excellent reputation for defending civil liberties and freedoms within their purview. It is therefore to be welcomed that the government relented by allowing judicial review of PSPOs by such bodies.

\section{CHALLENGING PSPOS OUTSIDE OF THE COURTROOM}

With limited scope available to challenge PSPOs in the courts, those opposed to PSPOs have sought to challenge them through the mobilisation of public protest. This has involved nationwide campaigns against the perceived misuse of PSPOs instigated by special interest groups as well as local campaigns against particular PSPOs. Three groups in particular have sought to mobilise resistance: Liberty (the civil liberties campaigning group); ${ }^{148}$ the Manifesto Club (an organisation that campaigns against the 'hyper-regulation of everyday life'); ${ }^{149}$ and the Keep the Streets Alive Campaign (a group that 'promotes shared use of Public Spaces by street artists, street performers, street musicians, campaigners, local residents, members of the public and other individuals and/or groups'). ${ }^{150}$ These groups have responded to local consultations raising concerns where they believe that civil liberties risk being adversely impacted upon. ${ }^{151}$ They have also used the publicity that they attract as organisations to encourage others to voice their concerns by participating in local consultations; for example, on 6 and 7 August 2016, a weekend of action was called by campaigners to protest against the misuse of PSPOs. ${ }^{152}$ Utilising social media, the hashtag \#PROTESTPSPO was used to promote events. Protests took place in a diverse range of locations, including Cambridge, Swindon,

146. Lords amendment 39 'Explanatory notes. Anti-social Behaviour, Crime and Policing Bill: explanatory notes on Lords amendments'; available at http://www.publications.parliament.uk/ pa/bills/cbill/2013-2014/0163/en/14163en.htm (accessed 17 September 2016).

147. Anti-social Behaviour, Crime and Policing Bill: Written Evidence (London: HMSO, 2013).

148. Liberty 'Public Spaces Protection Orders'; available at https://www.liberty-human-rights. org.uk/campaigning/public-space-protection-orders-0 (accessed 17 September 2016).

149. The Manifesto Club 'Public Spaces Protection Orders'; available at http://manifestoclub. info/category/pspos/ (accessed 17 September 2016).

150. The Keep the Streets Alive Campaign 'Our mission'; available at http://keepstreetslive. com (accessed 17 September 2016).

151. For examples, see Liberty, above $n$ 118; The Keep the Streets Alive Campaign, above $n$ 120.

152. The Manifesto Club '\#ProtestPSPO - 6 and 7 August'; available at http://manifestoclub. info/protestpspo-6-and-7-august/ (accessed 17 September 2016). 
the Forest of Dean and London. ${ }^{153}$ Campaigners were protesting against a diverse range of prohibitions, including a ban on chalk pavement art in Swindon and a proposed ban on sheep in the village of Bream.

Campaigners have had mixed success in persuading local authorities to withdraw or amend proposals for PSPOs. A useful case example where change was brought about following protests is that of a proposed PSPO that was to cover the city centre of Chester. Cheshire West and Chester Council launched a consultation in October 2015 proposing that the following prohibitions and requirements be attached to a PSPO covering the city centre:

- Prohibiting any verbal, non-verbal or written request - including the placing of hats or containers, or by performance or artistry - for money, donations or goods save on designated pitches and with the express permission of the Council.

- Prohibiting rough sleeping - 'No person shall lie down or sleep in or on any public space within the area. No person shall at any time deposit any materials used or intended to be used as bedding in or on any public place.'

- Feeding of birds in the designated area prohibited without express permission from the council.

- Prohibiting public urination/defecation.

- Prohibiting public consumption of alcohol unless in designated zones.

- Prohibiting ingestion of 'legal highs'. ${ }^{154}$

The consultation stated that a PSPO was needed because the city of Chester:

faces a number of long standing and quite complex challenges around anti-social behaviour and a number of issues have been raised by the community and businesses ... [W] e want measures in place to deter anti-social behaviour while, at the same time, ensuring that the appropriate support is available to protect some of the most vulnerable people in our society. ${ }^{155}$

The proposals proved controversial, particularly those provisions relating to the prohibition of rough sleeping, registration requirements on buskers, restrictions on begging and the prohibition on the feeding of birds in the city centre. The Keep Streets Alive Campaign criticised the proposals on busking for turning "council officials into civic Simon Cowells with a nasty twist, the power to give musicians a criminal record for singing songs on the streets'. 156

153. The Manifesto Club 'Weekend of action 06-07/08/16'; available at http://manifestoclub. com/protestpspo.html (accessed 17 September 2016).

154. Cheshire West and Chester Council 'Proposed draft of the PSPO'; available at http:// www.cheshirewestandchester.gov.uk/your_council/consultations_and_petitions/ council_consultations/proposed_public_space_protecti.aspx (accessed 17 September 2016).

155. Cheshire West and Chester Council 'Proposals for a Public Spaces Protection Order for the city of Chester: background information' (Chester: Cheshire West and Chester Council, 2015) p 3.

156. D Holmes "Chester busking proposals could turn council into "civic Simon Cowells" says campaigner' The Chester Chronicle 13 July 2015; available at http://www. chesterchronicle.co.uk/news/chester-cheshire-news/chester-busking-proposals-could-turn9643600 (accessed 17 September 2016). 
Comedian and campaigner Mark Thomas led a 'lying down' protest in the town hall square. ${ }^{157}$ Thomas, dressed in pyjamas and accompanied by buskers and others, some of whom were also in night-time attire, chanted and carried banners and placards with signs such as 'Say No to the PSPO' and 'Food Not Fines'. ${ }^{158}$ Representatives from a homeless outreach group and a number of homeless people themselves were also present at the protest. ${ }^{159}$

Using the local media interest that had been generated as well as social media, the various campaigning groups encouraged responses to the consultation. In the end, some 1,800 responses were received by the local authority. ${ }^{160}$ In addition, more than 15,000 signed a petition against the proposals. ${ }^{161}$ The consultation responses demonstrated opposition to the provisions in relation to rough sleeping, begging, bird feeding and busking. The council agreed not to include those provisions in the PSPO. ${ }^{162}$

There have been other prominent examples where local authorities have abandoned or amended plans for PSPOs in the face of organised opposition. In 2015, Newport City Council amended its proposals for a PSPO, dropping proposed restrictions on rough sleeping and leaflet distribution. ${ }^{163}$ In 2014, skateboarders successfully campaigned against a proposal by Norwich City Council to prohibit skateboarding in Norwich city centre. ${ }^{164}$ There were protests in Oxford in 2015 against proposals to prohibit 'rough sleeping' and 'persistent and aggressive begging'. ${ }^{165}$ The Oxford protesters placed cardboard 'beggar traps' at different points in the city to symbolically convey their point that the proposed PSPO would entrap those who beg into the criminal justice system. ${ }^{166}$ A petition with 66,000 signatories was gathered in opposition to the proposals. ${ }^{167}$ The proposals were

157. D Holmes "Comedian Mark Thomas leads Chester PSPO protest "lying-down" in city centre' The Chester Chronicle 17 September 2015; available at http://www.chesterchronicle. co.uk/news/chester-cheshire-news/comedian-mark-thomas-leads-chester-10077523 (accessed 17 September 2016).

158. Ibid.

159. Holmes, above $\mathrm{n} 157$.

160. A Charlesworth 'Rough sleeping ban scrapped in Chester' Big Issue North 17 March 2016; available at http://www.bigissuenorth.com/2016/03/homeless-ban-scrapped-in-chester/ 17565 (accessed 17 September 2016).

161. 'Optimism over potential U-turn over PSPO plans in Chester' Chester Standard 18 November 2015; available at http://www.chesterstandard.co.uk/news/155090/optimism-overpotential-u-turn-over-pspo-plans-in-chester.aspx (accessed 17 September 2016).

162. Charlesworth, above $\mathrm{n} 160$.

163. S Morris 'Plan to criminalise rough sleeping in Newport city centre dropped' The Guardian 24 November 2015; available at https://www.theguardian.com/uk-news/2015/nov/ 24/ban-homeless-people-sleeping-newport-proposal-droppde (accessed 17 September 2016).

164. 'Norwich city centre skateboard ban plan ditched' BBC Online 26 November 2014; available at http://www.bbc.co.uk/news/uk-england-norfolk-30210193 (accessed 17 September 2016).

165. H Summerville "'Beggar traps" being placed across Oxford in protest against council' The Oxford Mail 12 October 2015; available at http://www.oxfordmail.co.uk/news/ 13841182.Beggar_Traps_being_placed_across_Oxford_in_protest_against_council/(accessed 17 September 2016).

166. Ibid.

167. Oxford City Council 'City centre Public Spaces Protection Order report for City Executive Board' (Oxford: Oxford City Council, 2015); available at http://mycouncil.oxford.gov.uk/ documents/s23804/Report_City\%20Centre\%20PSPO.pdf (accessed 17 September 2016). 
amended to remove reference to rough sleeping and persistent begging, although provisions on so-called 'aggressive begging' remained. ${ }^{168}$

What these campaigns demonstrate is that local authorities can be persuaded to amend proposals for PSPOs during the consultation process, particularly where coordinated action is taken to exert pressure upon them. The campaigns also demonstrate that it is possible to mobilise opposition to more controversial PSPOs.

An inherent difficulty for those who wish to monitor the use of PSPOs is the localised nature of the legal tool. There are over 300 local authorities in England and Wales with authority to grant PSPOs. As local authorities are becoming more familiar with the legal remedy, an ever greater number of PSPOs are being introduced. Local authorities may have multiple PSPOs in place. As of 20 August 2016, Oxford City Council has two and has consulted on a third. ${ }^{169}$ Local authorities may also choose to amend PSPOs, adding additional prohibitions or requirements that may prove controversial. Further complicating matters is that local authorities will differ on the extent and format for any consultation process. It is therefore difficult for national campaigning bodies, such as Liberty or the Manifesto Club, to effectively monitor the proliferation of PSPOs, which in turn makes it difficult for them to assist in organising effective opposition in all cases. This means that effective resistance to a PSPO in an area will depend to an extent on the effectiveness of local opposition, which will vary from locality to locality. A postcode lottery of civil liberties is thus created, where a local authority in one part of the country may be dissuaded from introducing a controversial prohibition or requirement, whereas the same prohibition or requirement can be found in PSPOs granted by a local authority in another part of the country. An example of this are prohibitions on rough sleeping, which have been removed from proposed PSPOs in places such as the city of Chester following opposition, but are to be found in a PSPO passed by Shepway District Council in Folkestone. ${ }^{170}$

To improve matters, the government could introduce a requirement that before a local authority commences consultation on the introduction of a PSPO, or variation of one, a copy of the draft order is submitted to the Department for Communities and Local Government. The department could then publish the draft PSPO on a dedicated web page. Once a PSPO has been granted by the local authority, the final copy of the order would then also be submitted to the department. This process need not delay the introduction of an order or its variation, but it would prove a useful resource for monitoring the use of PSPO legislation. The web page could be used by campaigners concerned about civil liberties and other issues, to respond to consultations. It could also be used by local authorities to allow them to see examples of practice elsewhere, which should hopefully encourage greater consistency of use in PSPOs. The government would also be in a better position to monitor the implementation of legislation that delegates significant power to local

168. M McKenna 'Oxford City Council amends draft Public Spaces Prevention Order (PSPO) following concerns from homelessness organisations' Housing Excellence 20 May 2015; available at http://www.housingexcellence.co.uk/news/oxford-city-council-amends-draftpublic-spaces-prevention-order-pspo-following-concerns (accessed 17 September 2016).

169. Oxford City Council 'Public Spaces Protection Order'; available at https://www.oxford. gov.uk/info/20101/community_safety/274/public_spaces_protection_orders (accessed 17 September 2016).

170. Public Spaces Protection Order (Shepway District Council) 2015 No 1. 
authorities. This form of monitoring would be lighter touch than in relation to byelaws, which require central government approval. The storage of copies of every PSPO would also be a valuable tool for researchers who wish to study their use.

\section{CONCLUSION}

PSPOs offer local authorities in England and Wales extensive powers to regulate behaviour in public and quasi-public spaces through the use, or threat of use, of the criminal sanction. PSPOs exceed the limited powers associated with byelaws and the antisocial behaviour provisions such as the ASBO brought in by previous governments. They allow local authorities to create their own version of a public order criminal code for their locality.

Despite the extent of the powers granted to local authorities, there exists relatively limited scope to scrutinise and challenge the use of PSPOs. Unlike with byelaws, central government has no role to play in approving PSPOs. Central government does not even go so far as to monitor the use of the orders. Consultation requirements on local authorities wishing to introduce PSPOs are minimal and subject to local variation. Mechanisms for local councillors to democratically scrutinise PSPOs vary, with some councils delegating significant discretion to unelected officials to determine the content of PSPOs. The ability to challenge orders in the courts is restricted.

The campaigning work of the likes of Liberty and the Manifesto Club have brought some periodic limited national attention to the use of these orders in recent years; however, the inherently local nature of the PSPO means that it is at local level where the orders have sometimes gained the most publicity. On a number of occasions, proposed PSPOs have led to protests, mass consultation responses and reversals in policy from local authorities. However, in other areas opposition to similarly framed PSPOs has been more muted or local authorities have proven more resistant to opposition. The government no doubt would applaud the variation in approach as an example of localism in action. However, the existing framework for PSPOs has led to a postcode lottery, where the rights to exercise civil liberties in public spaces are curtailed for those living, working or visiting some parts of the country but not others.

The use of the PSPO has proven most controversial where it has been used to target more vulnerable sections of local communities. This includes the homeless targeted with anti-begging and rough sleeping provisions; children and young people targeted by age-specific exclusion zones or restrictions on gathering in groups or the use of skateboards; travellers and gypsies targeted by restrictions on where they can pitch their caravans; and buskers, street entertainers and street speakers targeted by provisions on the use of amplification requirement. Sometimes proposals targeting these groups have been defeated, but on other occasions they have been permitted to come into force.

The legislation governing PSPOs is framed in such a manner as to reduce the scope for judicial scrutiny, with limitations on who may instigate proceedings against a PSPO and when they can do so. To date, there has been no significant legal challenge to PSPOs in the courts. When such challenges do arise, it is important that the courts take the opportunity to clarify how the legal test should be applied and the types of restriction that are permissible.

The number of PSPOs continues to grow, as does their reach and the breadth of prohibitions and restrictions being placed on the use of public and quasi-public places. 
It is important that lawyers, policy makers and researchers are aware of these provisions, as vigilance at a national and local level is required to curtail the use of these orders that avoid due process, undermine civil liberties and target unpopular minorities. For the international reader, a watchful eye should be kept on any attempt to export the mechanism to other jurisdictions, as innovative methods of social control have a tendency to be applied elsewhere. 